\title{
VÁLLALATOK EGY
}

\section{NEUMANN-TÍPUSÚ GAZDASÁGBAN}

A dolgozat a klasszikusnak tekinthető Neumann-féle növekedési modell egy új alapra helyezését tartalmazza. Az eredeti Neumann-modellben expliciten vállalatok nem szerepelnek, csak technológiák vagy eljárások. A dolgozat egy olyan Neumann-típusú modellt vizsgál, amelyben az egyes technológiáknak vállalatokat feleltet meg, és azt vizsgálja, hogy ilyen feltételezés mellett egy ilyen gazdaságban léteznek-e olyan megoldások, amelyek mellett a vállalatok maximalizálják a nyereségüket. Ennek vizsgálata közben arra az eredményre juthatunk, hogy erre az esetre a klasszikus Neumann-modell által feltételezett nempozitív nyereséget felül kell vizsgálni, ami a klasszikus matematikai közgazdaságtan dualitáson alapuló alapfeltételezése.

Kulcsszavak: Neumann-modell, növekedési modell, optimalizálás, matematikai programozás

A Neumann-modellt tekintik ma a növekedési és egyensúlyelméletek egyik előfutárának. Ugyanakkor ez a modell felfogható úgy is, mint a Koopmans (1951) által kifejlesztett lineáris tevékenységelemzés dinamikus változata. A modell széles körben kutatott nemcsak az angolszász világban, hanem a magyar matematikai közgazdaságtanban is, csak néhány dolgozatot említve: Medvegyev (1984), Móczár (1995), Móczár (1997), Zalai (1999), Zalai (2004) ${ }^{1}$.

A klasszikus Neumann-modell gazdaságában $n$ terméket állítanak elő $m$ különbözô eljárás vagy technológia segítségével. A modell Neumann János által adott interpretációjában nem deríthető ki, hogy az eljárásokhoz vállalatokat vagy ipari ágazatokat lehet-e rendelni, netán több eljárás testesíti meg a vállalatokat. Amint az a modellból is kitúnik, az eljárások csak nempozitív nyereség mellett múködhetnek. Ez a vállalati gyakorlattal és a vállalat-gazdaságtanban oktatottakkal ellentétesnek tû́nik. A vállalat-gazdaságtan vállalatai nem létezhetnek középtávon (pozitív) nyereség nélkül, mert különben csődbe jutnak.

A dolgozat célja ezért az, hogy a klasszikus Neumann-modell egyes feltételezéseit megtartva egy új, más értelmezést adjon a bemutatandó modellnek. Az új értelmezésben tételezzük, fel, hogy a technológiák vállalatokat testesítenek meg. Arra építjük a módosított modell ezen értelmezését, hogy egy eljáráshoz egy vállalat rendelhetó. Ekkor a vállalatok ikertermékeket állíthatnak elô. Azt a modellváltozatot, amikor csak egy termék állítható elő az adott technológiával, LeontiefNeumann-modellnek nevezik.

A dolgozat az alábbi részekból áll. A következô részben a Neumann-modell egy dinamikus változatát mutatjuk be, aminek a stacionárius esetét, azaz egyensúlyi helyzetét vizsgálta Neumann (1945), majd Kemény, Morgenstern és Thompson (1956) gazdaságilag racionális feltételekkel bővítette azt ki. Ezen az eredeti modellen mutatjuk meg, hogy ha azzal a feltételezéssel élünk, hogy egy eljárás egy vállalatnak feleltethetô meg, akkor a nempozitív nyereség feltételezése esetén a vállalatok nyereségüket akkor is maximalizálhatnák, ha nem termelnének semmit. Ugyanakkor az így előálló zérus optimális kumulált nyereséget a modell klasszikus neumanni megoldása is garantálja, tehát a megoldások halmaza egy konvex halmaz. Ezért a nempozitív nyereség feltételezést helyettesítjük a nemnegatív nyereség feltevésével, amennyiben az eljárásokat vállalatnak (ágazatnak) tekintjük, mert az a gazdaság tevékenységeinek megszüntetését is jelenthetné, ha az optimális megoldások halmazából a vállalatok a semmittevés stratégiáját választanák. A harmadik fejezetben az átfogalmazott modellt vizsgáljuk. Amennyiben az eljárások vállalatoknak felelnek meg, akkor is azt kérdezhetjük, hogy milyen termelési szintek és árak mellett lesz a gazdaság egyensúlyban. Ennek a kérdésnek a megválaszolásához egy játékelméleti modellt vázolunk és röviden érintjük a modell megoldhatóságát. Végül összegezzük az eredményeket. 


\section{A Neumann-modell dinamikus változata és annak átfogalmazása}

Ebben a részben egészen bemutatjuk a Neumann-modellt. E dolgozatban nem célunk a Neumann-modell didaktikus bemutatása, azt Zalai (1999) dolgozatában aprólékosan megtette. A modell bemutatásakor nem a stacionárius, egyensúlyi megoldásból indulunk ki, hanem a turnpike-elméletben (Dorfman - Samuelson - Sollow [1958]) alkalmazott dinamikus lineáris programozási feladat megoldásából. E megoldás alapján azt vizsgáljuk, hogy vajon a Neumann-modell megoldása utat enged-e annak a megfeleltetésnek, hogy egy eljárás egy vállalatot takar.

\section{A Neumann-modell rövid összefoglalása}

A modell dinamikus változatát Asmanov (1984) munkája alapján ismertetjük. A modell alapmátrixait a Hegedús és Zalai (1978) könyvében található mátrixos jelölésekkel ismertetjük, a Neumann által használt hagyományosabb jelöléssel szemben.

A modell alapfeltételezései között szerepel, hogy a $j$-ik technológia egységnyi szintú alkalmazásához $c_{j}=$ $\left(c_{l j}, c_{2 j}, \ldots, c_{n j}\right)$ nagyságú induló készletre van szükség a termékekbốl, míg a termelési periódus végén egységnyi szintú alkalmazás esetén $d_{j}=\left(d_{1 j}, d_{2 j}, \ldots, d_{n j}\right)$ készlet áll rendelkezésre a piaci cserére. A $j$-ik technológia input-output összefüggéseit tehát a $\left(c_{j}, d_{j}\right)$ vektorpárral szemléltethetjük. A vektorok $n$ dimenziósak, vagyis a gazdaságban $n$ számú termék van, míg az eljárások száma $m$. Ha a $j$-ik technológia alkalmazási szintje a $t$-ik periódusban $x_{t}^{j}$, akkor az eljárás induló készlete $c_{j} \cdot x_{t}^{j}$ és a periódus zárókészlete $d_{j} \cdot x_{t}^{j}$. Az eljárással elő́lllított, és piacon értékesíthetô termékek mennyisége tehát $d_{j}$. $x_{t}^{j}$. A $t$-ik termelési periódus végén, a $t$-ik idópontban zajlik le a piaci csere az ott kialakuló áron, amelyet a $p_{t+1}=\left(p_{t+1}{ }^{l}, p_{t+1}{ }^{2}, \ldots, p_{t+1}{ }^{n}\right)$ nemnegatív $n$ elemú vektorral jelölünk. Az anyagáramlást a technológiák szempontjából az 1. ábra szemlélteti.

A Neumann-modell dinamikája a $j$-ik eljárásra

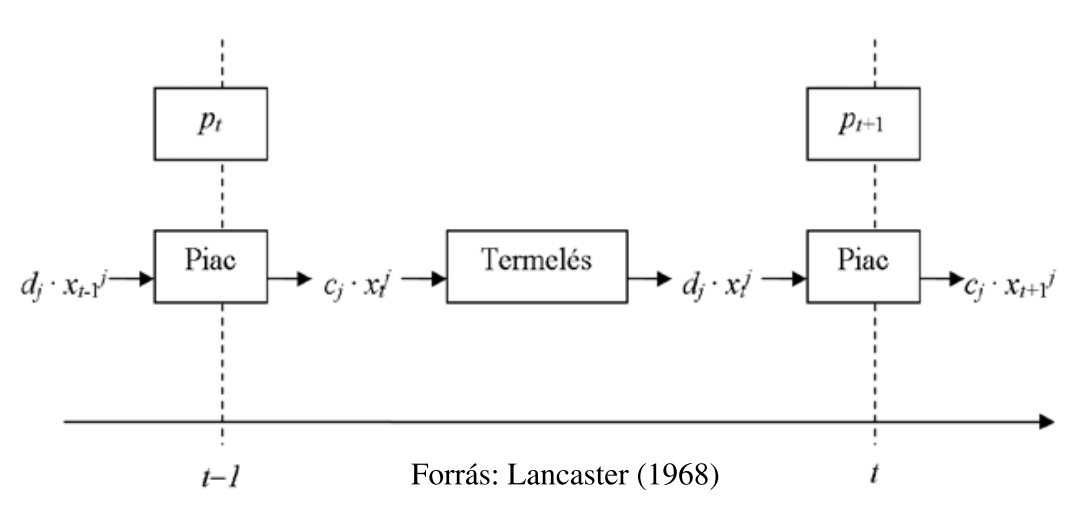

Foglaljuk most össze a gazdaságra az egyensúlyi feltételeket. A naturális egyensúly feltétele a $t$-ik idópontban az, hogy a piacra vitt termékek készlete a csere után nem lehet nagyobb, mint a csere előtt az egész gazdaságban, vagyis $D \cdot x_{t-1}-C \cdot x_{t} \geq 0$, ahol $C=\left(c_{p}\right.$, $\left.c_{2}, \ldots, c_{m}\right)$ és $D=\left(d_{l}, d_{2}, \ldots, d_{m}\right)$ a technológiák egységnyi input és output készletének mátrixa. Az $x_{t}=\left(x_{t}^{l}\right.$, $\left.x_{t}^{2}, \ldots, x_{t}^{m}\right)$ vektor a termelési szintek $m$ dimenziós vektorát jelöli a $t$-ik periódusban. A nempozitív nyereségre pedig a $p_{t+1} \cdot D-p_{t} \cdot C \leq 0$ összefüggés írható fel. Ha feltesszük, hogy a gazdaság tervezési időhorizontja $T$, akkor az induló készletek állománya $D \cdot x_{0}$, míg a terminális árbevétel összértéke $p_{T+1} \cdot D \cdot x_{T}$ kell, hogy legyen, ahol az $x_{0}$ kezdeti termelési szint és a $p_{T+1}$ végső árrendszer adottak. Ezenkívül a Kemény, Morgenstern és Thompson (1956) által javasolt feltételeket a modellhez csatoljuk, ami azt jelenti, hogy minden termék szükséges legalább egy másik termék előállításához: $1 \cdot C>0$, valamint minden termék elóállítható legalább egy eljárással: $D \cdot 1>0$, ahol az $1=(1,1, \ldots, 1)$ az öszszegzố vektort jelöli.

A következókben azt mutatjuk meg, hogy az előzőekben intuitívan kapott egyensúlyi feltételek egy lineáris programozási feladat primális és duális párjainak felel meg. A programozási feladat primális oldala a következő (1)-(4) feladat:

$$
\begin{aligned}
& x_{t} \geq 0,(t=1,2, \ldots, T), \\
& C \cdot x_{1} \leq D \cdot x_{\sigma} \\
& -D \cdot x_{t-1}+C \cdot x_{t} \leq 0,(t=2,3, \ldots, T), \\
& p_{T+1} \cdot D \cdot x_{T} \rightarrow \max .
\end{aligned}
$$

Ez a feladat késóbb a turnpike elméletek kiindulópontja volt, amely Dorfmann, Samuelson és Solow (1958) munkájában található meg. Ezek szerint, ha $T$ elég nagy, akkor az optimális pálya a Neumann-sugárhoz esik elég közel. (A Neumann-sugarat a következó bekezdésekben definiáljuk.)

1. ábra

A fenti feladat (5)-(8) duálisát az alábbi módon írhatjuk fel:

$$
\begin{aligned}
& p_{t} \geq 0,(t=1,2, \ldots, T), \\
& p_{t} \cdot C-p_{t+1} \cdot D \geq 0,(t=1,2, \ldots, T), \\
& p_{T} \cdot C \geq p_{T+1} \cdot D, \\
& p_{1} \cdot D \cdot x_{0} \rightarrow \text { min. }
\end{aligned}
$$

A két lineáris programozási feladat megoldható, mivel a $C$ és $D$ mátrixokra tett feltételek biztosítják egyrészt a primális feladat lehetséges megoldásainak halmaza korlátosságát, másrészt a duális feladat lehetséges megoldásainak 
halmaza alulról korlátosságát. Az optimális $\left(x_{t}^{o}, p_{t}^{o}\right)_{t=1}^{T}$ vektorpároknak ki kell elégíteniük a következó egyenlőségeket:

$$
\begin{aligned}
& p_{t}^{o} \cdot\left(C \cdot x_{t}^{o}-D \cdot x_{t-1}^{o}\right)=0, \\
& \left(p_{t}^{o} \cdot C-p_{t+1}^{o} \cdot D\right) \cdot x_{t}^{o}=0 .
\end{aligned}
$$

Vegyük most a probléma stacionárius megoldását, vagyis legyen $x_{t+1}=\alpha \cdot x_{t}$, valamint $p_{t+l}=\beta \cdot p_{t}$, akkor a stacionárius pályának ki kell elégítenie a

$$
\begin{aligned}
& D \cdot x^{e} \geq \alpha^{e} \cdot C \cdot x^{e}, \\
& p^{e} \cdot D \cdot x^{e}=\alpha^{e} \cdot p^{e} \cdot C \cdot x^{e}, \\
& p^{e} \cdot C \geq \beta^{e} \cdot p^{e} \cdot D, \\
& p^{e} \cdot C \cdot x^{e}=\beta^{e} \cdot p^{e} \cdot D \cdot x^{e}, \\
& p^{e} \cdot C \cdot x^{e}>0
\end{aligned}
$$

összefüggésrendszert, ami a Neumann-modell egyensúlyi helyzeteit foglalja össze. Az $x$ és $p$ vektorok nemnegatívak. A (11)-(15) egy egyensúlyi pályáját a $\left(\alpha^{e}, x^{e}, \beta^{e}, p^{e}\right)$ négyessel írhatjuk le, amit Neumannsugárnak neveznek. Ezekból a pályákból keressük a legnagyobb $\alpha^{e}$-t tartalmazó növekedési pályákat. A (11)-(15) modell egyensúlyi pályáinak létezésével nem foglalkozunk, az érdeklődő olvasó annak bizonyítását megtalálja pl. Hegedús és Zalai (1978) könyvében.

\section{Lehet-e a klasszikus Neumann-modellben vállalat egy eljárás?}

Most áttérünk annak a vizsgálatára, hogy mi történhet akkor, ha az eljárásokat vállalatoknak tekintjük, és ezzel folytatjuk elemzésünket. Ekkor a Neumann-féle gazdaságban fellelhető nempozitív nyereség feltételezését fel kell oldani, mert a vállalat-gazdaságtanban a nempozitív nyereség a vállalat megszúnéséhez vezethet, amint azt a következố példa mutatja. Elóbb vizsgáljuk a vállalat múködését, amit most azonosítunk a klasszikus Neumann-modell egy-egy eljárásával.

Az egyes vállalatok termékeit feloszthatjuk aszerint, hogy nyersanyagról, alapanyagról van-e szó, vagy végtermékről. Ezt a következő módon szemléltethetjük a $j$-ik vállalat esetén. Az $i$-k termék végtermék, azaz a piacon értékesíthetố termék, ha $d_{i j}>c_{i j}$ Ugyanakkor egy másik, $k$-ik termék nyersanyag, ha $d_{k j} \leq c_{k j}$. Így a $j$-ik eljárással elóállított termékek mennyisége a $t$-ik periódusban, ahol $i$ végterméket jelöl $\left(d_{i j}-c_{i j}\right) \cdot x_{t}^{j}>0$, míg a felhasználás $\left(c_{k j}-d_{k j}\right) \cdot x_{t}^{j} \leq 0$ a $k$-ik nyersanyag esetén. Itt azzal a feltételezéssel élhetünk, hogy a készletváltozást azonosítjuk a termeléssel és a termelőfelhasználással. Mivel a modell csak stock (állomány) jellegú mutatókat tartalmaz, ezért a flow (folyam) mutatókat a készletadatokból kell meghatároznunk.
A piacon az eljáráshoz, termeléshez felhasznált (így megsemmisített) terméket kell beszerezni, pl. a $t$-ik időpontban az $k$-ik termék esetén $c_{k j} \cdot x_{t}^{j}-d_{k j} \cdot x_{t-1}^{j} \geq 0$ nagyságban. Ezzel a mennyiséggel növekszik az eljárás lefolytatásához a következő periódusban rendelkezésre álló készletek mennyisége. Ugyanezen idốpontban az értékesítés mennyisége $d_{i j} \cdot x_{t-1}^{j}-c_{i j} \cdot x_{t}^{j}>0$. Ez a folyammutató a készletek csökkenését szemlélteti. Újra meg kell jegyeznünk, hogy a csere esetén is stock adatokból kell flow információkat előállítanunk. Ezzel az eljárással két tevékenységre bontottuk a Neumann-modellben megadott folyamatokat: termelésre és piaci cserére.

$\mathrm{Az}$ előbb bemutatott összefüggéseket a készletgazdálkodásból ismert stock-flow (állomány-folyam) egyenletek segítségével is szemléltethetjük:

$$
\begin{aligned}
& d_{j} \cdot x_{t}^{j}=d_{j} \cdot x_{t-1}^{j}+\left(d_{j}-c_{j}\right) \cdot x_{t}^{j}-\left(d_{j}-x_{t-1}^{j}-c_{j} \cdot x_{t}^{j}\right), \\
& (t=1,2, \ldots, T) .
\end{aligned}
$$

A vállalat a termelési folyamat során $\left(d_{j}-c_{j}\right) \cdot x_{t}^{j}$ mennyiségú terméket állít elô, illetve semmisít meg az előbbi bekezdésekben meghatározott értelemben, míg a piaci csere során $d_{j} \cdot x_{t-1}^{j}-c_{j} \cdot x_{t}^{j}$ nagyságú terméket értékesít, vagy szerez be a termelés folytatásához.

A vizsgált vállalat által elért piaci bevétel-kiadást a $t$-ik időpontban a $p_{t} \cdot\left(d_{j} \cdot x_{t-1}^{j}-c_{j} \cdot x_{t}^{j}\right)$ kifejezéssel írhatjuk le, ahol $p_{t}=\left(p_{t}^{1}, p_{t}^{2}, \ldots, p_{t}^{n}\right)$ vektor az árak $n$ dimenziós vektora a $t$-ik idôpontban. Ez csak a piaci árbevétel, de nem a nyereség. A nyereséget az egyes periódusokra értelmezhetjük, ami a $t$-ik periódusra $p_{t+1} \cdot d_{j}$ $\cdot x_{t}^{j}-p_{t} \cdot d_{j} \cdot x_{t-1}^{j}$. Ezt azért írhatjuk ebben a formában, mert két időszak „,mérlegfőösszege” közötti különbség lesz az eredménykimutatásban szereplő nyereség vagy veszteség a vállalat számára, amint az a vállalati számvitelben szerepel. Alakítsuk ezt az összefüggést tovább az alábbi módon, a (16) egyenletrendszert az árvektorral beszorozva:

$$
\begin{aligned}
& p_{t+1} \cdot d_{j} \cdot x_{t}^{j}-p_{t} \cdot d_{j} \cdot x_{t-1}^{j}= \\
& \left.p_{t+1}-p_{t}\right) \cdot d_{j} \cdot x_{t}^{j}+p_{t} \cdot\left(d_{j}-c_{j}\right) \cdot x_{t}^{j}-p_{t} \cdot\left(d_{j}-x_{t-1}^{j}-c_{j} \cdot x_{t}^{j}\right) .
\end{aligned}
$$

Ez azt mutatja, hogy a nyereség három részból áll, amelyek

- a Bródy (1980) által is leírt papírprofit:

$$
\left(p_{t+1}-p_{t}\right) \cdot d_{j} \cdot x_{t}^{j} \text {, }
$$

- a termelési tevékenység során képződő „belső” nyereség: $p_{t} \cdot\left(d_{j}-c_{j}\right) \cdot x_{t}^{j}$, és

- a piaci csere során kialakult áru-pénz egyenlege (árbevétel): $p_{t} \cdot\left(c_{j} \cdot x_{t}^{j}-d_{j} \cdot x_{t-1}^{j}\right)$.

Az eredeti Neumann-modellben az eljárások nyeresége nempozitív, tehát $p_{t+1} \cdot d_{j}-p_{t} \cdot c_{j} \leq 0$. 
Ezek után tételezzük fel, hogy az így megalkotott vállalat célja az árbevétel/ráfordítás maximalizálása a tervezési idôhorizonton. Feltesszük azt is, hogy az árak egy adott $T$ idóhorizonton belül adottak, és az (5)-(8) lineáris programozási feladat optimális megoldásával egyeznek meg. Nem foglalkozunk azzal, hogy milyen mechanizmus alakítja ki az optimális, egyensúlyi árakat, amit $p_{t}^{o}$-vel jelölünk, $t=1,2, \ldots, T$. A vállalat kumulált árbevételfüggvénye a vizsgált tervezési horizonton a következô alakot ölti:

$$
\begin{aligned}
& \sum_{t=1}^{T} p_{t}^{o} \cdot\left(d_{j} \cdot x_{t-1}^{j}-c_{j} \cdot x_{t}^{j}\right)+p_{T+1} \cdot d_{j} \cdot x_{T}^{j}= \\
& \sum_{t=1}^{T}\left(p_{t+1}^{o} \cdot d_{j}-p_{t}^{o} \cdot c_{j}\right) \cdot x_{t}^{j}+p_{1}^{o} \cdot d_{j} \cdot x_{0}^{j} .
\end{aligned}
$$

A vállalat célja tehát olyan termelési szintek kiválasztása, amely mellett az árbevétel maximális lesz, természetesen adott árak mellett. Tegyünk még egy feltételezést, ami az egyensúly naturális feltételéból következik:

$$
-d_{j} \cdot x_{t-1}^{j}+c_{j} \cdot x_{t}^{j} \leq \sum_{\substack{k=1 \\ k \neq j}}^{m}\left(d_{k} \cdot x_{t-1}^{k o}-c_{k} \cdot x_{t}^{k o}\right),(t=1,2, . ., T),
$$

ami azt jelenti, hogy a piaci csere korlátozza a vállalat által beszerzett és eladott áruk mennyiségét, ahol $x_{t}^{k o}$ az (1)-(4) modell optimális megoldása. Mindez azt is jelenti, hogy a vállalat maximális árbevétele függ a többi vállalat által értékesített és beszerzett termékek mennyiségétól. Itt feltesszük, hogy a vállalat számára ismertek a más vállalatok által piacon realizált egyensúlyi mennyiségek.

A (17) és (18) feltételezések felhasználásával a (19)(22) lineáris programozási feladatot definiáltuk, amely a következő formában írható fel:

$$
\begin{aligned}
& x_{t}^{j} \geq 0,(t=1,2, \ldots, T) \\
& c_{j} \cdot x_{1}^{j} \leq d_{j} \cdot x_{0}^{j}+\sum_{\substack{k=1 \\
k \neq j}}^{m}\left(d_{k} \cdot x_{0}^{k o}-c_{k} \cdot x_{1}^{k o}\right) \\
& -d_{j} \cdot x_{t-1}^{j}+c_{j} \cdot x_{t}^{j} \leq \sum_{\substack{k=1 \\
k \neq j}}^{m}\left(d_{j} \cdot x_{t-1}^{k o}-c_{j} \cdot x_{t}^{k o}\right),(t=2,3, . ., T) \\
& \sum_{t=1}^{t}\left(p_{t+1}^{o} \cdot d_{j}-p_{t}^{o} \cdot c_{j}\right) \cdot x_{t}^{j} \rightarrow \max
\end{aligned}
$$

A probléma megoldása könnyen megadható, ugyanis ha nempozitív az árbevétel, vagyis $p_{t+1}^{o} \cdot d_{j}-p_{t}^{o} \cdot c_{j}$ $\leq 0$, akkor az optimális termelési szint minden periódusban zérus, azaz $x_{t}^{j o}=0,(t=1,2, \ldots, T)$ is lehet. Ezt szekvenciálisan láthatjuk be, a bizonyítást a függelék tartalmazza. Ugyanakkor a célfüggvény (17) összefüggésnek megfelelő átalakítása során látható, hogy a (10) egyenlőség teljesülése miatt a neumanni megoldás, azaz az (5)-(8) lineáris programozási feladat megoldása is adja a zérus nyereséget. Mindez azzal a következménnyel járhat, hogy el kell vetni a nempozitív nyereség feltételezését ebben a modellben, vagyis akkor, ha az eljárásokat vállalatoknak, ágazatoknak tekintjük.

A továbbiakban feltételezzük, hogy nemnegatív nyereség fordulhat elő:

$$
p_{t+1} \cdot d_{j}-p_{t} \cdot c_{j} \leq 0,(t=1,2, \ldots, T),(j=1,2, \ldots, m) .
$$

Ez a feltételezés azt mondja ki, hogy egységnyi szintú múködés esetén a $t$-ik periódusra a termelési idôszak végi készlet értékének nagyobbnak kell lennie, mint az inputként szereplő készletek értéke. Ha ezt a feltételt nem tennénk meg, akkor a nempozitivitás miatt az optimális szintek értéke 0 lenne, amit nem tudnánk értelmezni.

A feltételezés ellentmondásban van a klasszikus Neumann-modell azon feltételezésével, hogy nem pozitív nyereséget értelmezünk. Azonban vállalatok modelljeként tekintve Neumann növekedési modelljét az eredeti feltételezés nem lenne - amint láttuk - tartható.

1. példa. Fejtegetésünket szemléltessük egy számpéldával. Tételezzük fel, hogy az alábbi két technológiával rendelkező gazdaságban három vállalat létezik, valamint két termék:

$$
C=\left[\begin{array}{lll}
1 & 3 & 5 \\
2 & 2 & 1
\end{array}\right], \quad D=\left[\begin{array}{lll}
3 & 1 & 3 \\
1 & 4 & 4
\end{array}\right] .
$$

Ebben a gazdaságban a vállalatok a következő termelési technológiával rendelkeznek.
1. vállalat: $d_{1}-c_{1}=\left[\begin{array}{c}2 \\ -1\end{array}\right]$,
2. vállalat: $d_{2}-c_{2}=\left[\begin{array}{c}-2 \\ 2\end{array}\right]$,
3. vállalat: $d_{3}-c_{3}=\left[\begin{array}{c}-2 \\ 3\end{array}\right]$.

Ez azt jelenti, hogy az elsố vállalat esetén a beszerzendô termék a második, aminek egy egységnyi felhasználásával kettô darab elsố terméket állíthat elô. A másik két vállalatra ugyanígy értelmezhetjük a vektorainkat.

Tegyük most fel, hogy az (1)-(4) és (5)-(8) feladatokat vizsgáljuk. Legyen a nulladik idôszak termelési szintje $x_{0}=[1,1,1]$, ami azt jelenti, hogy a nulladik periódus végén cserére rendelkezésre álló termékmennyiség

$$
D \cdot x_{0}=\left[\begin{array}{l}
7 \\
9
\end{array}\right] \text {. }
$$


Ugyanakkor tételezzük fel azt is, hogy három periódus termelési és árképzését vizsgáljuk. Ekkor legyen a negyedik periódus árvektora: $p_{4}=[1,1]$, amiból az egységnyi árbevétel (kiadás)

$p_{4} \cdot D=\left[\begin{array}{lll}4 & 5 & 7\end{array}\right]$.

Az (1)-(4) feladat induló és megoldási táblája a Microsoft Excel solveréból ekkor:
A célfüggvényben szereplő vektort a

$$
\left[\begin{array}{llll}
p_{1}^{o} & p_{2}^{o} & p_{3}^{o} & p_{4}
\end{array}\right] \cdot\left[\begin{array}{ccc}
-C & 0 & 0 \\
D & -C & 0 \\
0 & D & -C \\
0 & 0 & D
\end{array}\right]
$$

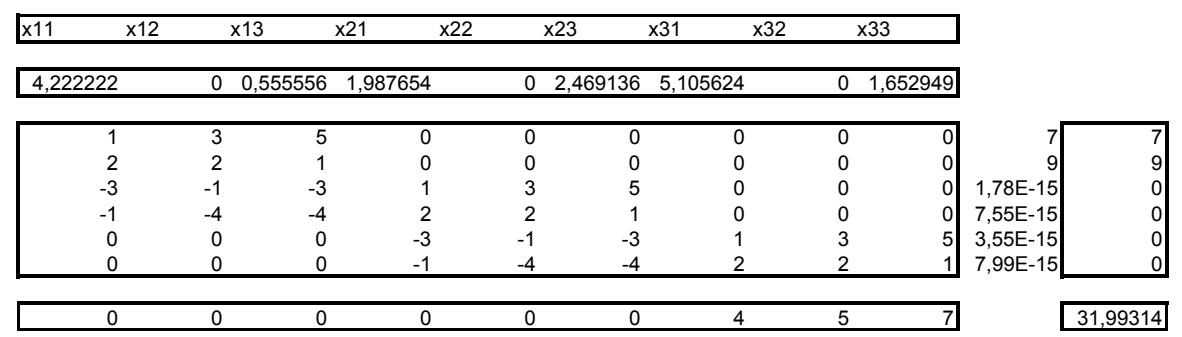

Innen látható, hogy az optimális megoldás a jobb alsó sarokban látható, ami nagyjából 32 pénzegység. Az optimális megoldást a második sor tartalmazza. Amint látható, a második vállalat nem fog termelni, mert a harmadik vállalat hatékonyabban állítja elő a második terméket.

$\mathrm{Az}$ (5)-(8) feladat megoldása, vagyis a Neumannrendszer megoldását a következő táblázat tartalmazza: múvelet elvégzésével nyerhetjük, amely az idôszaki termékekre esố nyereséget tartalmazza. Amint látható, ez a fajlagos zérus, ha a terméket termelik, és negatív, ha nem termelik.

Az optimális célfüggvény értéke zérussal egyezik meg, de az eredmény azt is mutatja, hogy az optimális termelési szintek ekkor erre a megoldásra szintén nullával egyeznek meg.

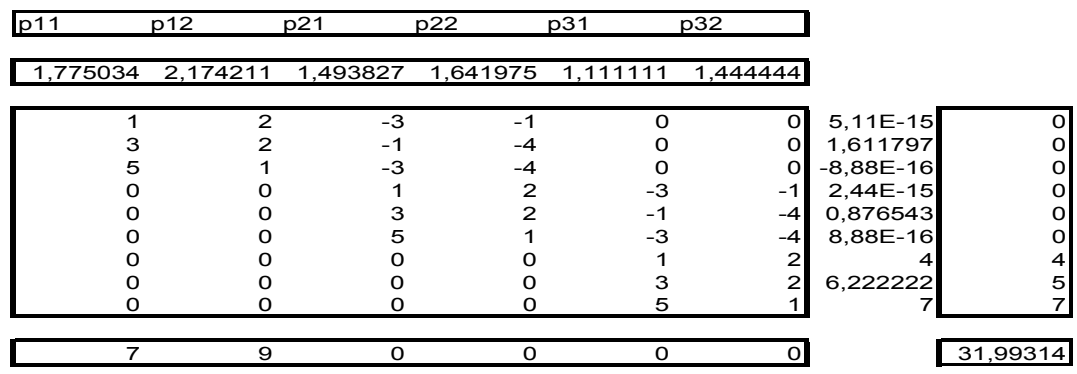

Ez a feladat duálisa az elóbbinek, ezért lesz az optimális célfüggvény értéke szintén mintegy 32 . Az optimális megoldásban a tervezési horizonton mindkét terméket termelik, hiszen pozitív a termékek árnyékára.

A következókben tételezzük fel, hogy az utóbbi árnyékárak a valódi piaci árak, és próbáljuk ennek segítségével maximalizálni a termelési szintek vektorait, amint azt a (19)-(22) feladatok is teszik. Ekkor az optimális megoldást szolgáltató Microsoft Excel tábla az alábbi:

\section{A Neumann-modell egy másfajta megfogalmazása}

A modellt a fentiek ismeretében a következő módon írhatjuk fel, mint a (23)-(28) optimalizálási feladatot:

$$
\begin{aligned}
& x_{t} \geq 0, p_{t} \geq 0(t=1,2, \ldots, T), \\
& C \cdot x_{1} \leq D \cdot x_{0}, \\
& -D \cdot x_{t-1}+C \cdot x_{t} \leq 0,(t=2,3, \ldots, T),
\end{aligned}
$$

\begin{tabular}{|c|c|c|c|c|c|c|c|c|c|c|c|}
\hline $\mathrm{x} 11$ & $\mathrm{x} 12$ & $\mathrm{x} 13$ & $x 21$ & $\times 22$ & $x 23$ & $x 31$ & $x 32$ & \multicolumn{2}{|c|}{$x 33$} & & \\
\hline & $\overline{0}$ & 0 & 0 & 0 & $\overline{0}$ & $\overline{0}$ & 0 & $\overline{0}$ & 0 & & \\
\hline & 1 & 3 & 5 & 0 & 0 & 0 & 0 & 0 & 0 & 0[ & 7 \\
\hline & 2 & 2 & 1 & 0 & 0 & 0 & 0 & 0 & 0 & 0 & 9 \\
\hline & -3 & -1 & -3 & 1 & 3 & 5 & 0 & 0 & 0 & 0 & 0 \\
\hline & -1 & -4 & -4 & 2 & 2 & 1 & 0 & 0 & 0 & 0 & 0 \\
\hline & 0 & 0 & 0 & -3 & -1 & -3 & 1 & 3 & 5 & 0 & 0 \\
\hline & 0 & 0 & 0 & -1 & -4 & -4 & 2 & 2 & 1 & 0 & 0 \\
\hline & -2 & & 0 & 0 & & 0 & 0 & & 0 & & 0 \\
\hline
\end{tabular}




$$
\begin{aligned}
& -p_{t} \cdot C+p_{t+1} \cdot D \geq 0,(t=1,2, \ldots, T-1) \\
& p_{T} \cdot C \leq p_{T+1} \cdot D \\
& {\left[\begin{array}{c}
p_{1} \cdot d_{1} \cdot x_{0}^{1}+\sum_{t=1}^{T}\left(p_{t+1} \cdot d_{1}-p_{t} \cdot c_{1}\right) \cdot x_{t}^{1} \\
p_{1} \cdot d_{2} \cdot x_{0}^{2}+\sum_{t=1}^{T}\left(p_{t+1} \cdot d_{2}-p_{t} \cdot c_{2}\right) \cdot x_{t}^{2} \\
\ldots \\
p_{1} \cdot d_{m} \cdot x_{0}^{m}+\sum_{t=1}^{T}\left(p_{t+1} \cdot d_{m}-p_{t} \cdot c_{m}\right) \cdot x_{t}^{m}
\end{array}\right] \rightarrow o p t,}
\end{aligned}
$$

ahol $D \cdot x_{0}$ az ismert készletállomány a tervezési periódus elején, valamint $p_{T+1} \cdot D$ egységnyi kibocsátás értéke a tervezési periódus legvégén.

A feladat így annak a $\left\{x_{t}\right\}_{t=1}^{T}$ termelési szerkezetnek és $\left\{p_{t}\right\}_{t=1}^{T}$ árrendszernek a felkutatása, ami mellett a vállalatok maximalizálják a nyereségüket. $\mathrm{A}$ vázolt probléma tehát egy játékelméleti, többcélú programozási feladat megoldását igényli. Matematikailag vizsgálva a problémát egy kvadratikus többcélfüggvényes matematikai programozási feladatot nyertünk. (Lásd pl. Krekó (1972) múvét.) Az ilyen feladatot visszavezethetjük egy egycélfüggvényes matematikai programozási feladattá, amennyiben a célvektort egy konstans $\lambda=\left(\lambda_{1}, \lambda_{2}, \ldots, \lambda_{m}\right)$ nemnegatív vektorral szorozzuk meg, amelyet az összegző vektorral szorozva éppen egyet kapunk, azaz l' $\lambda=1$.

A többcélfüggvényes programozás témaköréból ismert, hogy a megoldások halmaza nemkonvex, ugyanis az összes lehetséges $\lambda$ vektorra meg kellene oldanunk a problémát. A továbbiakban más utat választunk.

A feladat megoldását egyszerúsítsük arra az esetre, amikor a gazdaságban képződő összes nyereséget maximalizáljuk, azaz az elóbbi feladat célfüggvénye a következô alakot veszi fel:

$$
\sum_{t=1}^{T}\left(p_{t+1} \cdot D-p_{t} \cdot C\right) \cdot x_{t}+p_{1} \cdot D \cdot x_{0} \rightarrow \max .
$$

Ekkor $\lambda_{i}=\frac{1}{m}$.

A feladatot még egyszerúbb formában is felírhatjuk, ha az árvektorokat és a tevékenységi szintek vektorát, valamint a mátrixokat összevonjuk:

$\widetilde{x}=\left[\begin{array}{c}x_{1} \\ x_{2} \\ \ldots \\ x_{T-1} \\ x_{T}\end{array}\right], \quad \widetilde{p}=\left[\begin{array}{c}p_{1} \\ p_{2} \\ \ldots \\ p_{T-1} \\ p_{T}\end{array}\right], \quad \widetilde{C}=\left[\begin{array}{ccccc}C & 0 & \ldots & 0 & 0 \\ -D & C & \ldots & 0 & 0 \\ \ldots & \ldots & \ldots & \ldots & \ldots \\ 0 & 0 & \ldots & C & \\ 0 & 0 & \ldots & -D & C\end{array}\right]$.
Ennek segítségével a (23)-(28) probléma újabb, öszszevontabb alakja:

$$
\begin{aligned}
& \tilde{x} \geq 0, \tilde{p} \geq 0, \\
& \widetilde{C} \cdot \tilde{x} \leq a, \\
& \widetilde{C}^{\prime} \cdot \widetilde{p} \leq b, \\
& -\tilde{p} \cdot \widetilde{C} \cdot \tilde{x}+a \cdot \tilde{x}+b \cdot \tilde{p} \rightarrow \max
\end{aligned}
$$

ahol

$$
a=\left[\begin{array}{c}
D \cdot x_{0} \\
0 \\
\cdots \\
0 \\
0
\end{array}\right], b=\left[\begin{array}{c}
0 \\
0 \\
\cdots \\
0 \\
D^{\prime} \cdot p_{T+1}
\end{array}\right] .
$$

A vesszôvel a transzponáltat jelöltük. Mivel az így felvetett probléma egy kvadratikus programozási feladat, ezért még ez utóbbi feladatot is tovább egyszerúsíthetjük a (33)-(35) alakra:

$$
\begin{aligned}
& y \geq 0, \\
& E \cdot y \leq c, \\
& -\frac{1}{2} \cdot y^{\prime} \cdot E \cdot y+c \cdot y \rightarrow \max
\end{aligned}
$$

ahol

$$
y=\left[\begin{array}{c}
\tilde{p} \\
\tilde{x}
\end{array}\right], \quad E=\left[\begin{array}{cc}
0 & \widetilde{C} \\
\widetilde{C}^{\prime} & 0
\end{array}\right], \quad c=\left[\begin{array}{l}
a \\
b
\end{array}\right] .
$$

Ennek a feladatnak a megoldása Lagrangefüggvénnyel nem ad olyan szimmetrikus megoldást, mint a lineáris programozás dualitási eredményei, ezért eltekintünk annak vizsgálatától. A megoldás létezésének elemzésétól is eltekintünk, mert a mátrixokra tett Kemény, Morgenstern és Thompson (1956) feltételezések garantálják a (33)-(35) programozási feladat megoldását. Foglalkozzunk inkább e feladat stacionárius megoldásaival.

A stacionárius megoldás legyen újra $x_{t+1}=\alpha \cdot x_{t}$, valamint $p_{t+1}=\beta \cdot p_{t}$. Ekkor

$$
\begin{aligned}
& D \cdot x \geq \alpha \cdot C \cdot x, \\
& p \cdot C \leq \beta \cdot p \cdot D, \\
& p \cdot C \cdot x>0
\end{aligned}
$$

A $p$ árvektor és az $x$ termelési szintek vektora ebben az esetben is nemnegatív. Ez a modellváltozat tehát három ponton különbözik a klasszikus (11)-(15) Neu- 
mann-modelltől. Hiányoznak belőle a (12) és (14) dualitási tulajdonságok, valamint a (13) összefüggésben az egyenlőtlenség előjele megfordult. Az optimális $\alpha$ növekedési rátát és a $\beta$ árnövekedési rátát optimalizálási feladat megoldásaként kaphatjuk meg.

A modell megoldása így azon $(\alpha, x, \beta, p)$ egyensúlyi pályák felkutatása, amelyekre $\alpha$ maximális és $\beta$ minimális. Ha $\beta$ minimális, akkor $\frac{1}{\beta}$ nak maximálisnak kell lennie. Ez azt jelenti, hogy ebben a modellben nem kell minden vállalatnak maximális nyereséget elérnie, mint a klasszikus Neumann-modellben, hanem csak egy maximális nyereséget, amint azt a következő öszszefüggés mutatja:

$$
\frac{p \cdot\left(d_{j}-c_{j}\right)}{p \cdot c_{j}} \geq \frac{1}{\beta}-1 .
$$

A (39) képlet szerint a $j$-ik vállalat eszközarányos nyeresége nagyobb, mint egy adott érték, amit a garantált nyereségként definiálhatunk. Extraprofitot azok a vállalatok érhetnek el, amelyeknél a (39) egyenlótlen-

$$
\begin{aligned}
& x_{1}+x_{2}+x_{3}=1 \\
& \alpha \rightarrow \max
\end{aligned}
$$

A feladat megoldását szintén Microsoft Excellel elő lehet állítani: $x_{1}=0,648371, x_{2}=0, x_{3}=0,351629$.

Az optimális növekedési ütem: $\alpha=1,246616$.

A legalacsonyabb árnövekedést az alábbi feladat megoldása szolgáltatja:

$$
\begin{aligned}
& p_{1} \geq 0, p_{2} \geq 0, \beta \in \mathfrak{R} \\
& {\left[\begin{array}{ll}
p_{1} & p_{2}
\end{array}\right] \cdot\left(\beta \cdot\left[\begin{array}{lll}
3 & 1 & 3 \\
1 & 4 & 4
\end{array}\right]-\left[\begin{array}{lll}
1 & 3 & 5 \\
2 & 2 & 1
\end{array}\right]\right) \geq\left[\begin{array}{ll}
0 & 0
\end{array}\right.} \\
& p_{1}+p_{2}=1 \\
& \beta \rightarrow \min
\end{aligned}
$$

Az optimális értékek a következók: $p_{1}=0,411277$, $p_{2}=0,588723, \beta=0,871702$. A garantált profitráta ekkor $\frac{1}{\beta}=1,147181$, vagyis mintegy 15 százalék.

A (33)-(35) feladat megoldását az alábbi táblázat tartalmazza:

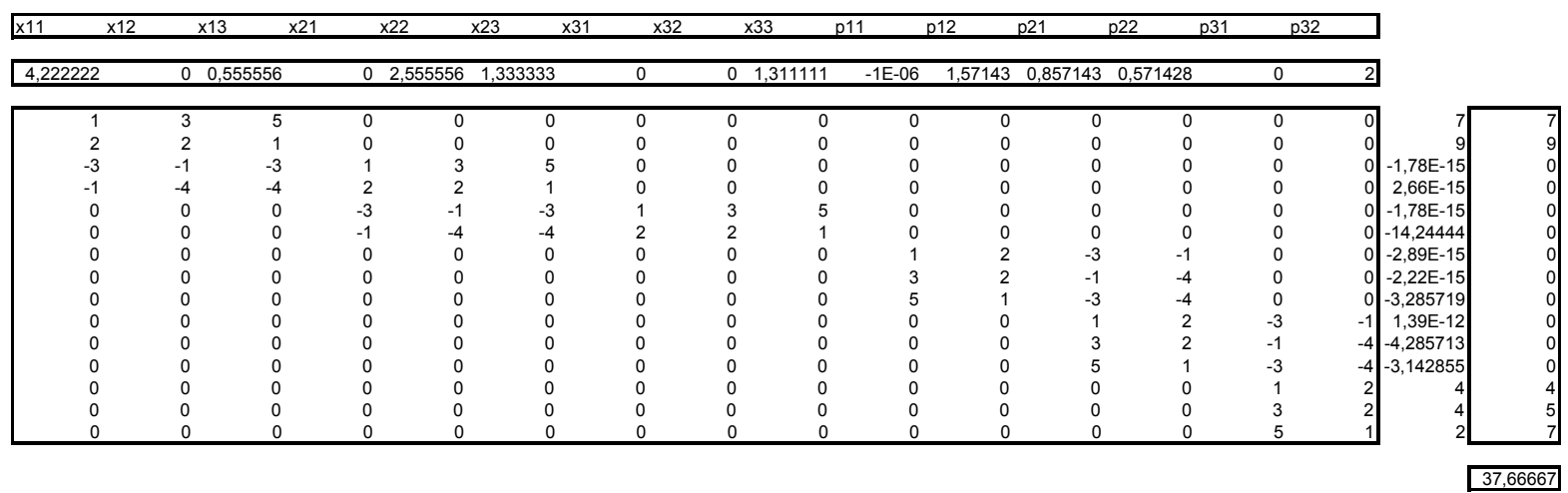

ség szigorú formában teljesül. Az extraprofit nagysága ekkor az $i$-ik vállalatra

$$
\frac{p \cdot d_{i}}{p \cdot c_{i}}-\frac{1}{\beta}>0 \text {. }
$$

Az egyensúly létezését Hegedûs és Zalai (1978) bizonyították. Ebben az esetben azonban a duális oldalról is hasonlóan bizonyítható az egyensúly létezése.

2. példa. Folytassuk az eredmények szemléltetését az 1. példa mátrixaival és vektoraival. Elôször az új értelmezés egyensúlyi termelési szintjeit és árvektorait a következő két feladat optimális megoldásaiként kaphatjuk meg: $x_{1} \geq 0, x_{2} \geq 0, x_{3} \geq 0, \alpha \in \mathfrak{R}$

$$
\left(\left[\begin{array}{lll}
3 & 1 & 3 \\
1 & 4 & 4
\end{array}\right]-\alpha \cdot\left[\begin{array}{lll}
1 & 3 & 5 \\
2 & 2 & 1
\end{array}\right]\right) \cdot\left[\begin{array}{l}
x_{1} \\
x_{2} \\
x_{3}
\end{array}\right] \geq\left[\begin{array}{l}
0 \\
0 \\
0
\end{array}\right]
$$

Az optimális megoldás ekkor a tervezési horizonton 37,666667, az optimális termelési szinteket és az árvektorokat a táblázat második, bekeretezett sora tartalmazza. Összevetve ezt a megoldást a klasszikus Neumann-modell megoldásával látható, hogy a gazdaság összes nyeresége majdnem hat pénzegységgel nótt.

\section{Összegzés}

A dolgozat abból a feltételezésból indult ki, hogy a Neumann-modell eljárásainak egy-egy vállalat (iparág) is megfeleltethetố meg. Feltételezve, hogy az így definiált vállalatok célja a nyereség maximalizálása, azt kérdeztük, hogy milyen feltételeknek kell teljesülnie az egyensúly eléréséhez. Arra az eredményre jutottunk, hogy a Neumann-modell eredeti feltételei közül kettő továbbra is teljesül, nevezetesen a naturális egyensúly, valamint az idôszak elejei készletek értékének pozitivi- 
tása, de az áregyensúlynak meg kell fordulnia, vagyis nemnegatív nyereségek kellenek, hogy legyenek az új modellben. Az új modellben a dualitási feltételekról is le kell, hogy mondjunk.

További kutatást igényel, hogy $\alpha$ és $\beta$ milyen feltételek mellett lehetnek azonosak. Ezenkívuil azt is kérdezhetjük, hogy hogyan alakul az egyensúly stacionárius feltétele, ha egy vállalat több eljárással (technológiával) rendelkezik.

\section{Lábjegyzet}

${ }^{1}$ A szerző köszöni Zalai Ernőnek a dolgozat korábbi változataihoz fưzött alapos megjegyzéseit. Minden további, dolgozatban maradó hiba és pontatlanság a szerzőt terheli.

\section{Felhasznált irodalom:}

Asmanov, Sz. A. (1984): Vvegyenyije v matyematyicseszkuju ekonomiku, Nauka, Moszkva

Bródy A. (1980): Ciklus és szabályozás, Közgazdasági és Jogi Könyvkiadó, Budapest

Dorfman, R. - Samuelson, P.A. - Sollow, R.M. (1958): Linear programming and economic analysis, McGraw-Hill Book Company, Inc., New York, Toronto, London
Hegedús M. - Zalai E. (1978): Fixpont és egyensúly a gazdasági modellekben, Közgazdasági és Jogi Könyvkiadó, Bp.

Kemeny, J.G. - Morgenstern, O. - Thompson, G.L. (1956): A generalization of von Neumann's model of an expanding economy, Econometrica 24, p. 115-135.

Koopmans, T.C. (Eds.) (1951): Activity analysis of production and allocation, John Wiley and Sons, New York

Krekó B. (1972): Optimumszámítás, Közgazdasági és Jogi Könyvkiadó, Budapest

Lancaster, K. (1968): Mathematical economics, CollierMacmillan Ltd, London

Medvegyev P. (1984): A general existence theorem for von Neumann economic growth model, Econometrica 52, p. 963-974.

Móczár J. (1995): Reducible von Neumann models and uniqueness, Metroeconomica 46, p. 1-15.

Móczár J. (1997): Non-uniqueness through duality in the von Neumann growth models, Metroeconomica 48, p. 280-299.

Neumann, J. von (1945): A model of general economic equlibrium, Review of Economic Studies 13, p. 1-9.

Zalai E. (1999): A közgazdaságtan metodológiájáról és a matematikai közgazdaságtanról a Neumann-modell ürügyén, Közgazdasági Szemle XLVI., p. 600-628.

Zalai E. (2004): The von Neumann model and the early models of general equlibrium, Acta Oeconomica 54, p. 3-38.

\section{Függelék}

A (19)-(22) probléma megoldását arra az esetre vizsgáljuk, amikor a fajlagos árbevétel/ráfordítás nempozitív, azaz $p_{t+1}^{o} \cdot d_{j}-p_{t}^{o} \cdot c_{j} \leq 0$. Azt látjuk be, hogy ekkor az optimális termelési szint minden periódusban zérus lehet, azaz $x_{t}^{j o}=$ $0,(t=1,2, \ldots, T)$. Ezt szekvenciálisan láthatjuk be.

Vizsgáljuk először az $x_{T}^{j}$ optimális értékét; feltételezve, hogy a többi optimális termelési szint $x_{t}^{j o},(t=1,2, \ldots$, $T-1)$ ismert. Az optimalizálási feladat alakja ekkor

$$
\begin{aligned}
& x_{T}^{j} \geq 0, \\
& c_{j} \cdot x_{T}^{j} \leq d_{j} \cdot x_{T-1}^{j o}+\sum_{\substack{k=1 \\
k \neq j}}^{m}\left(d_{k} \cdot x_{T-1}^{k o}-c_{k} \cdot x_{T}^{k o}\right), \\
& \left(p_{T+1}^{o} \cdot d_{j}-p_{T}^{o} \cdot c_{j}\right) \cdot x_{T}^{j} \rightarrow \max .
\end{aligned}
$$

Mivel a célfüggvény nempozitív, ezért annak felső korlátja zérus. Ezt az értéket akkor éri el a célfüggvény, ha az $x_{T}^{j o}$ optimális termelési szint nulla, vagyis $x_{T}^{j o}=0$. Ennek az összefüggésnek minden egyes vállalatra igaznak kell lennie, ezért $x_{T}^{j o}=0,(j=1,2, \ldots, m)$.

Tekintsük most a $(T-1)$-ik periódus optimális termelési szintjeit, ami a következő optimalizálási feladat megoldásaként áll elő:

$$
\begin{aligned}
& x_{T-1}^{j} \geq 0, \\
& c_{j} \cdot x_{T-1}^{j} \leq d_{j} \cdot x_{T-2}^{j o}+\sum_{\substack{k=1 \\
k \neq j}}^{m}\left(d_{k} \cdot x_{T-2}^{k o}-c_{k} \cdot x_{T-1}^{k o}\right), \\
& -d_{j} \cdot x_{T-1}^{j} \leq \sum_{\substack{k=1 \\
k \neq j}}^{m} d_{j} \cdot x_{T-1}^{k o}, \\
& \left(p_{T}^{o} \cdot d_{j}-p_{T-1}^{o} \cdot c_{j}\right) \cdot x_{T-1}^{j} \rightarrow \max ,
\end{aligned}
$$

ahol $(j=1,2, \ldots, m)$. Ennek a feladatnak a megoldása $x_{T-}$ ${ }_{1}^{j o}=0,(j=1,2, \ldots, m)$, amint azt az elózó optimalizálási feladat megoldásakor is láttuk.

Szekvenciálisan folytatva az optimalizálási feladatok megoldását azt kapjuk, hogy nempozitív árbevétel/ ráfordítás esetén a vállalatok optimális tevékenységi szintje zérus, azaz a semmittevés. Ezért abban az esetben, ha az eljárásokat vállalatnak tekintjük, akkor el kell vetni a nempozitív árbevételt, és helyette a nemnegatív árbevételt kell tennünk.

Cikk beérkezett: 2008. 10. hó

Lektori vélemény alapján véglegesítve: 2009 11. hó 